\title{
Feminine Behavior Management in Personal Selling Activities for Professional Male Makeup Artists
}

\author{
Ahmad Mulyana ${ }^{1}$, Parlin Harbert ${ }^{2}$ \\ ${ }^{1}$ Lecturer of Master Communication Program, Universitas Mercu Buana \\ ahmad.mulyana@mercubuana.ac.id \\ ${ }^{2}$ Master of Communication Program, Universitas Mercu Buana \\ herbertstan@gmail.com
}

\begin{abstract}
The research aims to describing the phenomenon of makeup artists or male beauty artists in promoting makeup services. They carry out personal selling activities for female customers through managing their feminine behavior. This research used symbolic interactionism theory with phenomenological research methods. It was conducted with qualitative case study method. The data collection technique used observation and in-depth interviews with informants who worked as professional male makeup artists. In addition to obtaining in-depth data, it was also carried out through secondary data for data enrichment so that it could obtain accurate, complete and comprehensive data.
\end{abstract}

Keywords_personal selling, management of feminine behavior, professional male makeup artists.

\section{INTRODUCTION}

\section{Background}

Personal selling as a marketing communication element has special advantages in communicating products. Excellence has meaning if the product to be communicated is a product with high-involvement category, such as product service category. It means that not all products are suitable to be communicated through personal selling. The product type is one of the important considerations in determining marketing communication form being suitable for persuading customers. Specifically, products are a set of tangible physical attributes that are related to an identifiable form. In general, the product is a set of real and unreal attributes which cover color, price, packaging, prestige and service of the factories and retailers that the buyers may accept as something that can satisfy their desires (Sthanton; 1996 \& Hafzi Ali; 2017).

Today's variation products in line with lifestyle is appearance and beauty products. These not only relate to cosmetics but also service products. The service products arise from appearance and beauty needs, i.e. makeup artist products. At the same time, it appears products that offer makeup artist services as well. The products develop when they become high-demand job among male and female millennials. Anyone can pursue this profession. Moreover, some young people can become a makeup artist (MUA) despite they do not have any special schooling. In fact, many also spend a lot of money when they take a course with a well-known makeup artist.

What is interesting is the fact that there are many men who have become makeup artists in Indonesia since 2000s. Women no longer dominate the role when men involve with the makeup artist profession. In other words, the competition map is no longer among female but women compete with men (http://duanews.blogspot.com). A sign of competition can be shown from Instagram social media from male makeup artists on Instagram media who advertise the success of makeup services business. As uploading amazing makeup results on Instagram accounts, male makeup artists can attract lots of followers and many new clients want to use their makeup services. The male image as a makeup artist remains a series of prototypes right now. In general, the view of society assumes woman's position as weak, gentle and protective whereas man acts as household head who protects his family strongly. The view of society is a situation related to what is called gender. Therefore, in the makeup artist profession there is gender competition. However, the behavior focus remains the needs of female customers who put forward the characteristics of feminist behavior. Researchers' interests in this phenomenon and attention to know more about male makeup artists when they manage feminine behavior in conducting personal selling. Moreover, the research purpose to be conducted in this research is to get an overview of the personal selling management through the 
competency of impression management in the profession of male makeup artist. Based on the description above, a series of questions is as follows:

1) What underlines feminine behavior of a male makeup artist when doing personal selling?

2) How is the implementation of feminine behavior that a male makeup artist carries out when doing personal selling?

3) Why is feminine behavior of a male makeup artist a competency for the male makeup artist when doing personal selling?

\section{CONCEPTUAL FRAMEWORK OF THE STUDY}

This research relates to personal selling that plays an important factor as the determinant of success in corporate marketing activities. The use of personal selling is intended to build customer relationships, creative sales and company representation to customers. So far, the previous research concludes that personal selling still becomes a very important promotional tool with high value products and complex customer products to promote and increase sales (Gunawan \& Japarianto: 2016). Another research comes from Yousif (2016) concerning the effects of personal selling on cloth buying behavior among teenagers. Amanda M. Gengler (2011) conducts the study on the approach of feminine style sale and women's consumption patterns. Sandra Pauser, Udo Wagner \& Claus Ebster (2015); Sunil Erevelles and Nobuyuki Fukawa (2013) and Adefulu Adesoga (2016) conducted another research on personal selling.

The aforementioned researches conclude that personal selling builds and maintains the benefits of customer relationships in a kind of increasing satisfaction level. Moreover, the researches confirm that clients get the right service quality and information can be modified according to customers' needs. Personal selling requires interpersonal communication competency to convince consensus. It is why personal selling tends to be used to communicate products in the service category. Interpersonal communication is communication that occurs at certain levels with a various number of participants. Interpersonal communication occurs between two people who have close relationships so that they can convey feedback in many ways (Miller in Alo Liliweri: 2015). Interpersonal communication is a procedure that makes two people exchange information and feelings through verbal and non verbal messages. This definition underlines the important fact that interpersonal communication not only concerns with "what" it is spoken but also "how" the way the language is spoken (Liliweri, 2015).
Interpersonal communication competency definitely support the success of personal selling and therefore the marketing communication objectives are achievable. Marketing communication consists of two important elements, i.e. communication and marketing. In general, communication is the process of delivering messages whenever communicators conduct to communicants through certain channels and it will regenerate cognition, affection and psychomotor of the message recipients.

Philip Kotler and Kevin Lane (2016: 27) state: "marketing is about identifying and meeting human and social needs." According to the definition, marketing is identifying and meeting human and social needs. Marketing communication objectives are: (1) Information and promotion: communication is used to influence customers and prospective customers to buy products using mass communication; (2) The process of image formation. Communication is used to influence several stages of purchasing process that customers carry out; (3) Relationships. Communication is used as a means to unite various forms of relationships that organizations and customers build.

According to Trence A. Shimp (2010: 281), personal selling is a form of individual communication where a salesperson relates to prospective buyers and tries to influence them and therefore, they buy his/her products or services.

Personal selling (Kotler and Armstrong, 2004) is one of the effective promotional tools on some set of preferences, beliefs and actions. In this matter, an individuals who conduct personal selling activities must be able to build impression in every communication activity they do. Goffman in his book entitled "The Presentation of Self in Everyday Life" mentions the term of self presentation with management impression. Definitely, Goffman emphasizes that this world is a stage of theatrical performance. Each individual manages things they do when interacting with others, and it is called dramaturgy. In a performance there are front stage, back stage, performance team (group or team who are involved when supporting the performance and audience (community)). Impression management is defined as one's activities look good for others and himself (West and Turner, 2008, 146) while Erving Goffman (1959) states that impression management is a process by which people control how others perceive them (Anderson and Taylor, 2011).

Related to the gender concept which addresses feminine behavior, D. Haraway mentions that gender is built as a category to explore the meaning as "woman", and it asks what was ever considered taken for granted. Therefore, the term 'gender' appears on behalf of a 
relationship problem between women and men. At least, the term 'gender' refers to three things: (1) The social construction of masculinity and femininity in social roles;

(2) Behavior (social and personal closeness); (3) Individual identity that is known from outside on the basis of 'natural' sex differences. The use of the term 'gender' in feminist literature also has various objectives. It describes social normative framework in which discrimination occurs. Moreover, as a critical tool for feminists the term is used to overcome women oppression. Finally, as a meaning in which feminists can explain different identities that contain either being non-male or being absorbed in a (considered male) society. According to the article written by Rijalulhaq, 2011 in www.kompasiana.com some men characteristics show dominant feminism will have behavior pattern as follows:

1) Physically he is male but his speech style is like a woman

2) His hand and body movement tend to be graceful

3) He follows fashion trends

4) He pays attention to his appearance (his uses of cosmetics and speciaized mens grooming products)

5) He carries out activities / gather with women (like to gather and gossip)

6) He frequently brings tissue, love romantic melancholic songs

7) He has sensitive feelings

8) His silence can harbor a great potential for anger

\section{RESEARCH METHODS}

To answer the research questions, the researcher uses case study method. According to Bogdan and Bikien (1982), case studies are in-depth and detailed examination of one background or subject or document storage or particular event. Surachmad (1982) restricts case study as an approach that focuses attention on an intensive and detailed case. Moreover, Yin (1987) provides more technical boundary and puts the emphasis on its characteristics. Ary, Jacobs, and Razavieh (1985) explain that in case studies, researchers should examine units or individuals in depth. The researchers try to look for typifications as important findings in this research. With the rationale, it is understandable that the limitations of case studies include: (1) the relevant research objectives can be in a kind of individuals, events, background and documents; (2) the targets are observed and examined in depth as a totality in accordance with their respective contexts in the aim of obtaining a comprehensive understanding in relation to the existing elements. Bogdan and Biklen (1982) in Burhan (2010) state that qualitative data analysis is a study conducted with the ways of : a. working on the basis of natural data

b. organizing and reducing data

c. sorting data into units that can be classified

d. synthesizing the data

e. searching and finding thematic patterns

f. discovering what is important and what is learned

g. deciding what can be told to others.

The data collection in this research uses two kinds of data collection methods, i.e.:

a. Primary data is information obtained from the firsthand source. Primary data the researchers will use is in a kind of text observation.

b. Secondary data is additional data that help strengthen information in a research. The use of the secondary data is literature studies and images attached in the comments column.

Moreover, according to Bogdan \& Biklen (Moleong 2005: 248), qualitative data analysis is a way of "organizing, categorizing and sorting out and grouping data into manageable units, synthesizing, searching and finding patterns, identifying important things and deciding what can be recommended to others".

The stages of data analysis in qualitative research begin with analyzing the collected data from various sources of evidence, i.e. in-depth interviews, list of observations that have been written in field notes, personal documents, official documents, pictures, images, and others. Notes divide into two, i.e. descriptive and reflective notes (Muhadjir, 2000: 139). The descriptive notes are made in natural settings and present events what they are rather than summaries of them. The reflective notes address the scheme of thoughts, ideas, and attention from the framework of the researchers' thoughts, ideas and concerns. These also express researchers' comments on the observed phenomena.

\section{FINDINGS AND DISCUSSION}

\section{Reality of Feminine Behavior for Professional Male Makeup Artists}

The use of marketing communication forms in supporting marketing activities definitely depends on product character being marketed. Products with the lowinvolvement category such as fast moving products tend to use conventional marketing forms and mass media to communicate products in a kind of advertising, sales promotion and publicity. However, marketing products with the high-involvement category such as service products usually uses qualitative approach to customers, and therefore marketers usually use a form of personal selling communication. 
It also occurs to service products like makeup artists. The customers of makeup artists are mostly women. In this matter, approach and persuasion to women requires understanding so that the services they provide are not only beautiful makeup but also must be able to make them comfort. They will be more comfortable if their needs as women are served in beauty makeup process. For female professional makeup artists this condition does not become a big problem. As women they have sufficient understanding of female customers' needs.

It differs from professional male makeup artists (MUA). The male MUA must have additional competence so that their services get favor from female customers. As men they must understand the women's world particularly being able to build comfort with a woman.

From the researchers' observation to the male MUA who are carrying out beauty services, they develop feminine behavior when providing their services to female customers. The intended behavior has a behavior pattern that can be described as follows :

1) Despite he is physically male, his style of speech is like female and it is better known from his tone of voice and word choice or verbal language.

2) His hands and body movements tend to be graceful which can be seen in non verbal expressions

3) Fashion becomes the main focus in his daily appearance

4) He pays attention to appearance (using cosmetics and speciaized mens grooming products)

5) He does gathering activities with women (he likes to gather and gossip)

6) He often brings tissue, love romantic melancholic songs

7) $\mathrm{He}$ is sensitive in interacting with female counterparts

Feminine behavior is an important part of the interaction between professional male MUA and women customers. From the observations the researchers had made, when the beauty service process was carried out, the professional male MUAs displayed feminine behavior with their customers. The professional male MUAs in the interactions try to provide their customers comfort and satisfaction when they manage the impression that their female customers have loyalty to the male MUA services.

Based on the researchers' observation to the professional male MUA phenomena when they interact with female customers, it can be described as follows:

As self-promotion behavior, it means that individuals who play roles in accordance with their abilities or achievements must be seen as competency. This self promotion shows a description of attention to personal achievements that indivuals can achieve, and therefore, they seems to have competency. The individuals are very competent, effective and successful.

- As a pleasant effort with the behavior of frequently praising the others, and it means that the individuals use flattery or provide support in an effort to be seen as something pleasant.

- Exemplary behavior. It means that individuals behave by positioning themselves above and beyond the call of duty. Therefore, it shows that they are dedicated individuals. Individuals who want to become the exemplary behavior feel that they always want to be respected and admired due to their integrity and moral honesty. In the exemplary behavior as discussed at above, the male makeup artist cannot give example to himself that his own makeup results is successful. However, he gives example to prospective customers in a kind of his personal grooming, such as clean, non-greasy, spotty face, fragrant body and clean nails. Therefore, prospective customers see makeup results to the male makeup artist himself who looks clean and fragrant. As Retnayu stated. "... it is not impossible that the male makeup artists dress up like a woman using lipstick and others. Indeed there are the male makeup artists something like that. However, there are also the male makeup artits who only show their feminine side by showing their neat and fragrant appearance and sometimes their appearance are more fragrant and their faces are smoother than mine ... "(Oscar Daniel)

- As the behavioral effort to softly bind the relationship, it means that a person frequently tries to make persuasion and has persuasive ability. Moreover, he/she wants others to see him/her as respected man/woman. "... licking in the positive terms, certainly we can do. In this matter, we sell and give support to prospective customers when they feel insecure by giving them little praise. So, they have full of confidence.

- As the begging behavior, it means that individuals describe their deficiencies and it is an effort to be considered as an incapable or poor person. In the begging behavior it is described that a person can meet an obligation he/she must do but do not want to show it.

To further explore the observation results, the researchers carried out interviews with three male makeup artists (Vidi Daniel, Oscar Daniel and Jerry Michael). Some Indonesian 
artists whom Vidi Daniel had successfully made up are among others, i.e.: Mulan Jamila, Venna Melinda, Vera Zanobia, Chatherine Pamela, Cut Memey, and Miss Universe Indonesia 2013 Wulandhari Herman. Through interviews with the MAUs, the researchers obtained information about the aspects underlying the feminine behavior of a male makeup artist, i.e. as personal selling activities. The above statement emphasizes that managing their feminine behavior is a personal selling activity. It is confirmed in Haryanti (2009: 16) that there are three characteristics in personal selling :

1) Personal confrontation: personal selling includes living, direct and interactive relationships between two people or more. Each party observes the reactions of the others more closely

2) Strengthening: personal selling may emerge various types of relationships that range from selling relationships to friendship ones.

3) Responses: personal selling makes the buyers feel obliged to listen the salesperson's conversation.

The information above will be deepened by exploring data that will answer how and why the feminine behavior management is implemented in the personal selling activities of the professional male MUAs.

\section{Feminine Behavior Management conducted by Professional Male MUAs}

Informant Oscar Daniel stated that he previously worked as a finance officer at one of the companies in Jakarta. An Oscar Daniel's interest to be a male makeup artist began in 2001. When Oscar and his friends made a wedding organizer, he always got the job as a bride's companion. Moreover, in 2005 Oscar had the opportunity to meet a well-known male makeup artists Adrian Surya Pradipta. Oscar also studied with Adrian Surya Pradipta for six months while he helped Adrian as his male makeup artist assistent. Oscar also had opportunity to make up Adrian's customers. In 2006, Oscar boldly declared himself a professional makeup artist. Oscar did not yet satisfied with his skill as a male makeup artist and he decided to deepen his makeup skill in Singapore in 2007. Until now, Oscar has been known as the male makeup artist whose followers on Instagram were more than 22,000 followers. Oscar Daniel's skill was ever tested when he made up The Princess of Kingdom of Belgium The Royal Highness Princess Kristine de Bagration Mukharani.

Informant Jerry Michael was a graduate from Faculty of Economics at one of the leading universities in Greater Jakarta. Starting from working as a business development at one of Jerry's beauty clinics, he began to get know the makeup world. He got support from his close friends and relatives, in 2011 Jerry boldly took a makeup course. Jerry's journey to become a male makeup artist was not as easy as people think. Before he decided to become a professional male makeup artist, Jerry strongly stigmatized himself that a male makeup artist would get the nickname "bencong" (a feminine man).

They explain that the feminine behavior appeared from a man is normatively considered against nature, strange and awkward for the people of Indonesia. However, in big cities like Greater Jakarta, along with the lifestyles change particularly extraordinary fashion trend, it makes men possible to taking part in feminine activities. Feminine behavior is no longer the women's domain. A male makeup artist has association with feminine views in society and the feminine behavior definitely does not have something in the male makeup artists. Vidi Daniel stated that, "I have no desire to behave feminine when I carry out my profession as a male makeup artist. The underlying factor is totally my work environment as the male make-up artist. I have to interacts directly with my customers who are mostly women.". Oscar Daniel and Jerry Michael also said similar ones, "... it is deniable that a lot of interactions with our customers who are mostly women inadvertently construct us to be feminine. Our speak style is more subtle. However, I do not want to be called feminine in an environment outside my profession I do everyday.

\section{Impression Management of Male Makeup Artists Front Stage}

However, concerning the real purpose as male makeup artists, Vidie Daniel, Oscar Daniel and Jery Michael honestly stated, "The main goal is to build a relationship with prospective customers and therefore, we make them comfortable. The customers will comfortably choose them and keep using our services." It can be achieved when they make interactions with their customers. The male makeup artists carry out verbal and non verbal management. Therefore, it is self-management to portray the front and rear stage. The front stage presents an expression of self presentation and it focuses on impressions that can make comfort and provide solutions to the needs and desires of their female customers and therefore, they will decide and choose the services of the male make-up artists. Through the interaction with feminine behavior, they becomes loyal customers. Vidi Daniel confirmed it:

"... customer approach is very important. I always approach the prospective customers by asking what they need, giving presentations about the service results I have given, providing solutions to whether the 
makeup services are appropriate to their face or something else. With this way, prospective customers feel comfortable when they talk with me in my communication style and gesture. When customers start feeling comfortable with what we reveal there, it will be easier to make them potential customers."

The interview results illustrate persuasion efforts when persuading customers through interpersonal communication approach both verbally and non-verbally with the aim of promoting the services of the male makeup artists. therefore, they can satisfy the needs and desires of female customers who want maximum beauty with a sense of comfort.

In more detail Oscar Daniel stated, "... gesture and dress style, neat appearance, clean face (no dry spotty skin) and clean nails are very important when we carry out the profession as the male makeup artists. It aims to convince customers that as the male makeup artist I can make them beautiful according to what they dream through my selfpresentation with clean, neat and fragrant appearance." With this way, Oscar Daniel is actually conducting personal selling activities with the sample or example of the make artist makeup services through his appearance. Therefore, the brand equity value emerges from a male makeup artist. The difference also occurs when a male makeup artists makes personal selling to prospective customers. It is vividly expressed in the statement of Vidi Daniel:

"... as a professional male make up artist we already have long experiences in the makeup world. There are many prospective customers who do not understand the types of cosmetic products we use (the male makeup artists), we will certainly give the best makeup results. However, the prospective customers feel more understood than us. One of them asks why I have to use layered lashes. My eyes are big enough, so I'm afraid my eyes are heavy and so on "(Vidi Daniel)

According to Kotler and Amstrong, one step in conducting personal selling is to deal with objections. In overcoming the objections, a salesperson must use a positive approach and he/she will dig out hidden objections. Firstly, ask buyers to explain objections. Secondly, use objections as an opportunity to provide more information and change objections to be a reason to buy.
The main goal in personal selling is to persuade prospective customers and therefore, they get feed back in a kind of purchasing the service products (makeup products) and finally they can become loyal customers in future.

Personal selling is not managed intentionally when carrying out their profession as a makeup artist as admitted by Vidi Daniel "... because he has been running the makeup artist profession for quite a long time, the feminine behavior sometimes arises accidentally. It occurs after he has met many potential customers who are mostly women. Therefore, feminine behavior appears. Both in terms of appearance and body gesture, it has to be controllable. Not everyone likes the style and gesture of feminine men. "This is conducted unconsciously" ... Onconsciously feminine behavior will appear in conducting personal selling particularly when the male makeup artists meet with potential customers. It aims at convincing the prospective customers. This feminine behavior is usually limited to clean, fragrant and other appearance and it does not prevail for makeup as well." (Oscar Daniel)

In more detail, Vidie Danil stated: "It would all come out by itself, particularly in today's era there remain many customers who argue that if a male make-up artist will definitely be feminine. So when meet them, sometimes the prospective customer will definitely use slang or similar ones. Therefore, I accidentally use the slang or with more feminine gesture to make them feel comfortable and they understand when making convestation. What is certain is that the goal is these customers are able to purchase my make-up products ..." (Oscar Daniel)

For men with the profession of makeup artist, first impressions are very important. These will determine the continuation of subsequent communication in the use of makeup artist services among female customers. It includes impression management and it will encourage the level of approval through personal selling activities they carry out implicitly. Melly Moxie argued, "With feminine behavior from a male makeup artist through gestures, his fashionable appearance is even more fragrant than women themselves. It can make a woman customer comfortable, and he can talk about various conversation topics. It is just seen from the front. However, many male makeup artists whom I know when we gather are not as neat and nonfeminine as when they work or look feminine. Moreover, they do not think about their hair, faces and clothes. Thier speaking style looks like men in general. "(Oscar Daniel)

\section{Back Stage}


As the social nature of man, it is carried out normally. The back stage management as the social nature of man runs normally. Vidie Daniel stated:

"... in life outside of my profession as a male makeup artist, I never behave feminine from my speaking style to behavior. I go to fitness. I go with my parents and my friends. I also do other activities that do not emphasize my feminine aspect. Moreover, I join with friends who have different professions."

Together with Vidie, Jerry Michael underwent a normal back stage life as a man outside the profession as a male makeup artist. Jerry Michael stated as follows:

"... It is not as complicated as imagined. At least we have to be neat. It starts from hair. Face should not dull, It also prevails to nails, fragrant and mostly important our clothes. It should not be expensive. As long as it is neat and clean. Most of our prospective customers see appearance from the front side. They do not need to know what is behind us. My life outside of meeting potential customers, I do not need to think about my appearance. Even when I am off work I don not even take a shower ... "(Jerry Michael)

"... when working as a male makeup artist my physical appearance and others have to be drawn attention. Otherwise, when I am off work, I am just a Vidi Daniel who live an ordinary life, wake up, take a shower, go to the gym, and meet friends without thinking about my appearance like I have to go to work." (Vidi Daniel)

Furthermore, Vidi Daniel stated:

"When I am at home with my family, it is impossible for me to maintain my appearance which is always fashionable, fragrant, neat hair and particularly talking in the feminine style. However, when I meet my prospective customers, I will pay attention to all my performances. It is the front stage I becomes a living male makeup artist. Otherwise, if I do not work (the back stage) I do not worry about my appearance. I do not use moisturizer and even hair wax: "(Vidi Daniel)

Otherwise, Jerry places himself not as a male makeup artist with feminine behavior.

"I do not put myself as a male makeup artist with feminine behavior and I do not display my feminine side. It is definitely true that there are many male makeup artists get influence from the environment. However, I always try not to behave feminine particularly when I conduct personal selling to my customers despite the feminine characteristics appear unconsciously."

Ralph LaRosa and Donald C. Reitzes note the assumptions underlying the Symbolic Interactionism Theory. Seven assumptions show three major themes, i.e. :

1) Meaning. The importance of meaning for human behavior

The Symbolic Interaction Theory assumes that meaning is created through interaction and modified through interpretation. It also assumes that how human beings interact with others depends on the meaning that other human beings provide. Therefore, effective communication will not occur without the shared meaning. We will be easily to communicate with those who have the same language with us if compared to those who do not have the same language.

2) The importance of self-concept

Symbolic Interaction Theory assumes that the self-concept develops through interaction with the others and gives motive to behave. According to William D. Brooks, the self-concept is the perception of our psychological, social, and physical self that we obtain through experience and interaction with the others.

3) Relationships between individuals and society This theory also assumes that culture and social processes influence human beings and groups and therefore, social structures are determined through the types of social interactions. This theory considers how social norms and culture become individual behavior.

In this research, the symbols that emerge from the behavior of the male makeup artists are feminine behaviors to represent what they mean when they communicate with potential consumers. Therefore, there is significantly influence that arises from the feminine behavior is 
generated in the social interaction between the male makeup artists and their consumers.

Ralph LaRosa and Donald C Reites state the basic assumption on the importance of meaning in human behavior. The meaning is created through interaction and modified through interpretation. It assumes that the self concept is made through interaction between the male makeup artists and their consumers. It provides motives and goals from the feminine behavior they generate. The motive is to get sales.

The relevance between the theory and the research is that in social interaction a male makeup artist seeks to present his image or self-concept as a male make-up artist. He reveals professional life as a male makeup artist and life outside the profession in the front stage and the back stage consecutively.

Moreover, in carrying out personal selling definitely relates to interpersonal communication that service providers and prospective consumers have built. The interpersonal communication is the main key of personal selling conducted to build relationships, create boundaries, overcome differences and provide input, and therefore it makes customer satisfaction in the personal selling activities. The impression management is the added value when carrying out personal selling. Concerning the consumers, the male makeup artists places themselves as women who want to be beautified with the makeup services. Therefore, the impression that the consumers desire can be built with the interactions that the male makeup artists have made.

From this research it is also found that the feminine behavior of the male makeup artist can be described in the following research scheme:

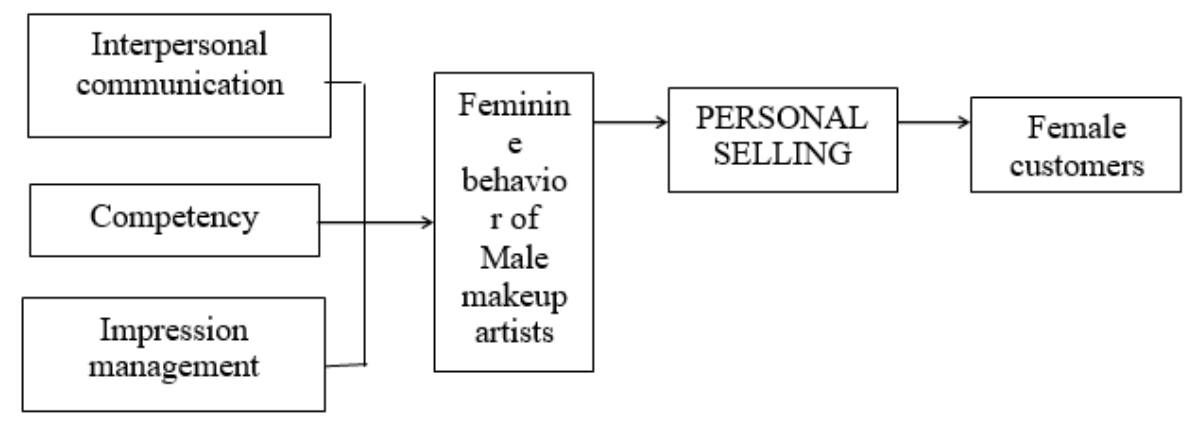

Fig.1: Scheme of feminine behavior management in Personal selling of Male makeup artits (MUA)

From the scheme of research results above, researchers can explain that feminine behavior can be divided into two parts, i.e.:

1) Feminine behavior physically found in Impression Management Theory only displays the front stage. And this factor gets support from the environment of their profession.

2) Feminine behavior that is genetically inherited from birth gets support from the presence of environmental factors and others factors that build man's feminine behavior.

From the description above, it is found that there is shift in the meaning of the feminine behavior in one's profession, in this matter a male makeup artist when carrying out personal selling. However, it can be also stated that this phenomenon is a reality where the profession demands interaction in the professional sphere and it wants to present the image of a male makeup artist in the front of potential customers. They manage the front stage that displays social performances with the feminine male features through fashionable styles, clean faces, fragrant bodies and others. From the interpersonal communication between the male makeup artists and prospective customers they establish symbols through gesture and speaking style. Therefore, it provides feminine impression ... However, personally Vidi Daniel stated:

"... when working as a male makeup artist my physical appearance and others must be disclosed. However, when I do not work, I am just a Vidi Daniel. I live in an ordinary life. I wake up and take a shower. I go to the gym and meet my friends without thinking about appearance like I have to go to work "

This shows that the phenomenon of the behavior management is a professional fact. Indeed life outside their profession, they do not think of appearance. And their environmental factors make them (the male makeup artists) feminine behavior like this. The perspective shows that the phenomenon occurs above is an activity of human characteristics, i.e. communication or exchange of symbols that provide meaning. This research relates to the presence of symbolic symbols through bodily gestures expressed by a male makeup artist. From the symbols, there is exchange of symbols with the feminine meaning. This perspective 
suggests that human behavior must be seen as a process that allows humans to shape and regulate their behavior by considering the expectations of others who become friends in their interactions. The definitions they give to others, objects and even themselves determine the human behavior.

In this context, the meaning is constructed in interaction process and it is not a neutral medium that allows social forces to play its role, i.e. actual substance of social organization and social power. (Mulyana, 2002, 6878) According to Artur Asa Berger (2004: 14), Symbolic Interaction Theory shows that life is basically human interaction with the use of symbols. They are interested in the way human beings use symbols that represent what they mean when communicating each other. And the influence results from the symbolization of the behavior among the parties in social interaction. (Sobur, 2004, 1999).

\section{CONCLUSION}

1. The competency of the professional male makeup artists includes the ability to build closeness to customers by managing feminine behavior when they interact with mostlyt female customers.

2. The management of feminine behavior is the result of interaction with feminism in general, and therefore it becomes behavior inherent in the MUA profession.

3. Professional male makeup artists not only rely on hardskill ability, i.e. the ability to make up female customers but also require interpersonal communication competency. It can make female customers comfortable when they make impression management whether it is verbally and nonverbally. Moreover, they package it in feminine behavior while carrying out the function of personal selling to develop their business. When they do not function as a male makeup artist professionally, they behave like most men.

\section{REFERENCES}

[1] Adesoga, Adefulu. 2016. Exemination of The Relevance of Personal Selling In Marketing Activities. Jurnal of Accounting and Management, vol. 02, page 103-116.

[2] Adefulu Adesoga, Examination Of The Relevance Of Personal Selling In Marketing Activities: A Descriptive Methode, Journal of Accounting and Management 2016, vol. 06 no. 02 , page $103-116$.

[3] Ali, Hafzi, et.all. 2017. The Influence of Quality Products, Price, Promotion, and Location to Product Purchase Decision on Nitchi At PT. Jaya Swarasa Agung in Central Jakarta, Saudi Journal of Business and Management Studies.
[4] Ani, Ratanasri Nur. 2014. Pesan Komunikaasi Antarpribadi Sebagai Pencegah Terjadinya Konflik Pada Hubungan Persahabatan Remaja Di Samarinda, E-Jurnal Ilmu Komunikasi.

[5] Agnihotiri, Adam. 2008. The Sales Force Technology Performance Chain - The Role of Adaptive Selling and Effect. Journal of Personal Selling and Sales Management. Issue 4. Vol XXVIII.

[6] Astuti, Linda Dwi. 2016. Penerapan Perssonal Selling Pada Strategi Pemasaran Produk Indi Home Di PT Telkom Kandatel Bantul.

[7] Catanti, Winda Karunia 2017. Pengaruh Personal Selling Dan Word Of Mouth TerhadapKeputusan Pemilihan Kursus Bahasa Inggris Pada The Dafoldis Di Kecamatan Pare Kediri, Jurnal Pendidikan Tata Niaga.

[8] Ervellas, Sunil. 2016 The Role of Affect In Personal Selling and Sales Management. Jurnal of Personal Selling \& Management, Vol XXXIII.

[9] Gunawan,Melisa. 2016. Pengaruh Visual Merchandising, Personal Selling Dan Product Quality Terhadap Purchase Intention Pada Produck Kosmertik LT PRO di Surabaya. Jurnal Management Pemasaran. 2016. Vol 10.

[10] Irawan Swastha Basu \& Manajemen Pemasaran Modern. John C Candon Fathi Yousef An Introduction to Intercultural Communication .- New York : Macmillan , 1986 . - Vol. 127.

[11] Julie Ann C. Ocon and Magdalena G Alvarez, The Implication Of Personal Selling Strategies In Motivation Approaches And Good Grooming. The international conference on communication and media 18-20 October 2014, Langkawi, Malaysia.

[12] Kotler, Phillip and Lane, Kevin. 2016. Manajemen Pemasaran. Jakarta: Erlangga.

[13] Liliweri Alo. 2015. Komunikasi Antar Personal. Jakarta: Kencana Prenada Media Group.

[14] Mulyana, Deddy. 2016. Ilmu Komunikasi Suatu Pengantar. Bandung: PT Remaja Rosdakarya.

[15] Oesman, Yevis Marty. 2002. Perilaku Konsumen dan Pemasaran Strategik. Bandung: Linda Karya.

[16] Ocon, Ann C. 2014. The Implication of Personal Selling Strategies In Motivation Approcahes And Good Grooming. The International Conference on Communication.

[17] Rudain Othman Yousif. 2016. The Impact of Personal Selling on the Purchasing Behavior towards Clothes: A Case Study on the Youth Category. International Journal of Marketing Studies, Vol. 8, No.4.

[18] Sandra Pauser, Udo Wagner \& Claus Ebster. 2015. An Investigation of Salespeople's Nonverbal Behaviors and Their Effect on Charismatic Appearance and Favorable Consumer Responses. Journal of Personal Selling \& Sales Management, Vol.5 No.2.

[19] Sunil Erevelles and Nobuyuki Fukawa. 2013. The Role Of Affect in Personal Selling and Sales Management. Journal of Personal Selling and Sales Management. DOI: 10.2307/23483316, 2013. 